\title{
Whatever happened to God's holiness? The holiness of God and the theological authenticity of the South African neo-Pentecostal prophetic activities
}

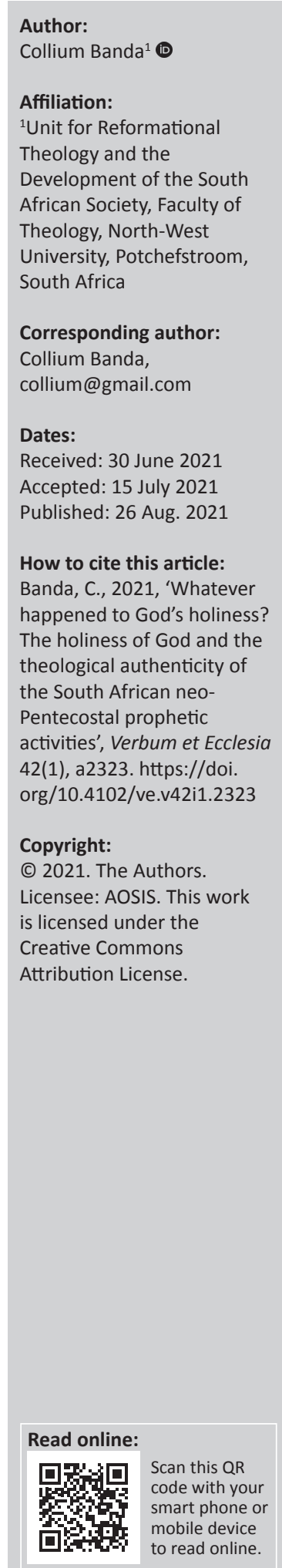

The controversial activities of the neo-Pentecostal prophets (NPPs) in South Africa raise many theological questions. From a systematic theological perspective that affirms the importance of Christian doctrines in regulating church worship and practice, this article uses God's holiness to evaluate the theological authenticity of the NPPs' controversial activities. The research question answered in the article is: how can an understanding of the holiness of God empower Christian believers to respond meaningfully to the controversial practices? The article begins by describing the theoretical framework of God's holiness. This is followed by describing the NPPs' shift from prophecy focusing on holiness to one focused on human needs. Furthermore, this shift among the NPPs from holiness to human needs is attributed to celebrity cultism through which the prophets thrust themselves as powerful figures who are able to solve people's problems. Afterward an analysis is made of how the holiness of God is violated by the NPPs' controversial practices. Finally, some steps are suggested for NPPs and their followers to take to align their activities with God's holiness. The contribution of the article lies in highlighting the importance of God's holiness as a standard of measuring the Christian authenticity of the controversial activities of the NPPs in South Africa.

Intradisciplinary and/or interdisciplinary implications: The article uses insights from the doctrine of God's holiness, the role of biblical prophecy and the doctrine of the church, to critique the controversial activities of the NPPs in South Africa.

Keywords: holiness; neo-Pentecostal prophets; celebrity cultism; South Africa; spiritual fear; neo-Pentecostal practices.

\section{Introduction}

Controversial neo-Pentecostal prophets (NPPs) continue to dominate the South African religious sphere in ways that raise questions about the moral character of the modern Christian churches, and the character of the God being worshipped in those churches. The controversial NPPs points to the new Pentecostal prophetic movement that is different from the classical conservative Pentecostalism (CCP). As will be later discussed, NPPs have been widely reported in the media performing various puzzling acts such as spraying people with poisonous insecticides and making people eat grass. At the time of writing, some prominent prophets are currently undergoing trial in South African courts for some of these activities because of their criminal nature. These unusual and unconventional practices make it necessary to evaluate them in the light of God's holy character which he also demands from those who worship him. Some of the reported controversial activities are blasphemous, abusive and dehumanising. These practices make a mockery of God, his people and the Christian religion in general.

The research question which this article attempts to answer is: how can an understanding of the holiness of God assist Christian believers to respond to the controversial practices among NPPs in South Africa? This question will be answered from a systematic theological framework that recognises the role of Christian doctrines in informing and regulating Christian living and practices. The research question is answered through the following steps: firstly, the theoretical framework of the holiness of God is defined. Secondly, a distinction is made of how prophecy among NPPs has shifted from holiness to solving human problems. Thirdly, it is further argued that the shift from holiness to human needs is driven by celebrity cultism through which prophets thrusts themselves as powerful individuals who can solve people's problems. Fourthly, an analysis is made of how the holiness of God is violated by the NPPs' controversial practices. The article closes by offering some steps that NPPs and their followers should take in order to align 
their activities to God's holiness. The contribution of the article lies in highlighting the importance of the holiness of God as a standard of measuring the Christian authenticity of the practices of the NPPs in South Africa.

\section{The holiness of God as a theoretical framework for analysing controversial neo-Pentecostal prophets}

The holiness of God is used from a systematic theological perspective to examine and critique the prophetic authenticity of the controversial practices of the NPPs. Although Chimuka (2013, 2016) has examined the morality and holiness of African NPPs, he however, limits the discussion to questions about whether these prophets derive their prophetic powers from God or from African traditional spiritual sources and the plea for African NPPs to be recognised as an authentic Christian phenomena. Chimuka does not take the debate to a deep theological analysis of the nature of God's holiness. God's holiness encapsulates moral purity and moral excellence which means that God 'is separated from sin and devoted to seeking his own honour' (Grudem 1994:201). God's holiness means that it is difficult to associate him with the controversial activities reported among some NPPs. Holiness is a communicable attribute of God which he shares with his people and also determines how God relates with his people. Holiness also determines how God's people should relate with him as their God and with other human beings. An understanding of God's holiness can function as a protective mechanism against abusive and dehumanising religious practices conducted in the name of God by regulating behaviour in the church.

Systematic theology is essentially concerned about what the Bible says about any given topic (Grenz \& Olson 1996:39; Grudem 1994:21). In this case, the article is concerned with what the Bible teaches on the holiness of God and how this holiness can be a bulwark against the controversial and abusive practices of the NPPs. To committed Christians, there is an inseparable link between doctrinal beliefs and moral conduct which means that systematic theology and theological ethics are intertwined since beliefs about God have direct implications on practical living. A theological reflection on the holiness of God is ultimately an ethical reflection.

The main method used to extract and analyse data combines literal analysis and media analysis. Kgatle's (2021) book: Pentecostalism and Cultism in South Africa, is a significant example of the use of literature and media analysis methods in studying recent developments in the NPP churches. Although literature on NPPs is growing exponentially, Kgatle (2021:9) says literature alone is insufficient to understand the pervasiveness of NPPs in South Africa because a large portion of their teachings is in the form of videos and audio clips. Media analysis includes the analysis of videos and audio clips. Neo-Pentecostal prophets are in the forefront in the use of media such as newspapers, radios, television, and social media platforms such as YouTube, Facebook and Twitter. The advantage of media analysis is that some platforms such as YouTube indicate the number of people who have watched the videos and at times it provides space for responses and interactions with those who have watched the videos. This helps to indicate how the prophets' followers are receiving the message. Therefore, the material on the NPPs extracted from literature and media sources will be interacted with from a systematic theological view of the holiness of God.

\section{Neo-Pentecostal prophets and their shift from holiness-focused prophecy to anthropocentric prophecy}

The term 'NPP' refers to a complex South African Pentecostal phenomenon that is radically different from CCP. Both movements share a Pentecostal heritage rooted in the 1906 Azusa Street Revival, in Los Angeles, United States of America. It is however possible to link some of the NPP practices such as faith healing to the pre-1906 Azusa Street Revival healing movements in Europe and North America, that were led by figures such as J.C. Blumhardt, Dorothea Trudel, Charles Cullis, John Alexander Dowie, Carrie Judd Montgomery and A.B. Simpson (Anderson 2013:16). Both movements share common Pentecostal beliefs such as baptism in the Holy Spirit leading to speaking in tongues, the spiritual gifts for all believers, divine healing and prophecy.

A fundamental characteristic of the NPP movement is the prophetic figures who are foundational to both the rise and the survival of their prophetic churches. Kgatle (2020:3) emphasises that prophecy is the most significant feature of the new prophetic churches and is the source of their growth in South Africa. However, CCP also recognises itself as a prophetic movement with roots in the Old and New Testament prophets and lays a strong emphasis on the fulfilment of the Joel prophecy in Acts 2. But the major difference is that in CCP, prophecy is strongly linked to holiness or sanctification, spiritual revival and the spiritual endurance of the Christian community. However, among NPPs, prophecy can be described as anthropocentric prophetism because it is primarily concerned with solving human problems in the present earthly life. It is this anthropocentric view of prophecy which opens room for the questionable activities reported among NPPs.

Some scholars refer to the NPPs as 'new Pentecostal churches' (Tsekpoe 2019:6) or 'new prophetic churches' (Kgatle 2021:6) to emphasise their unique focus on human centred prophecy. In this article, the term ' $\mathrm{NPP}^{\prime}$ is preferred because 'neopentecostal' highlights the new form of Pentecostalism expressed by these prophets (Ramantswana 2019:4), while 'prophets' or 'prophetic' indicates the prophetic characteristic of these churches (Kgatle 2020:3). The prophetic movement is growing in South Africa, and across Africa, as new prophetic 
figures are constantly entering the prophetic space. The movement is complex and riddled with intense competition among the various prophets who have sometimes clashed publicly and even questioned each other's prophetic credentials (Dube 2020; eNCA 2019; Jordaan 2019b; Multimedia Live 2019).

The neo-Pentecostal shift from holiness oriented prophecy to anthropocentric prophecy is reflected in the general practice of 'diagnostic prophecy' (Anderson 2013:126-127). Diagnostic prophecy specialises in revealing people's problems and their causes and includes what Kgatle (2019:1) calls 'forensic prophecy, prophetic titles, prophetic objects, prophetic consultation and prophetic miracles'. All these aspects open avenues for the prophet to diagnose people's problems and prescribe the necessary interventions such as anointed oil or paying a certain sum of money. Essentially, the prophetic element of the NPPs includes healing and 'signs and wonders'. Diagnostic prophecy can also include elements of sanctification and repentance such as when a person is told that they need to confess and repent of what they did that is causing them to be sick, or when one is told to strengthen their prayer life.

However, it cannot be entirely denied that NPPs do actually preach the gospel of spiritual salvation even though they tend to primarily function as problem solvers and end up taking multiple roles such as exorcists, medical practitioners, economists, financial advisers, fertility specialists, and gynaecologists. Therefore, it can be argued that NPPs do point people to Jesus Christ, especially when one considers that they attribute their miracles to God as indicated by the signature statement: 'Glory to Jesus' or 'Glory to God' at the end of miracles. However, the NPPs' commitment to a truly Christ-oriented gospel and spiritual revival is compromised by how they 'preach messages that are motivational instead of [soteriologically] challenging and confrontational' (Kgatle 2021:143). Although NPPs are generally effective communicators who communicate and dramatise the gospel message in simple ways that are easily accessible to many Africans, they however, 'do not preach messages that will address sin in the church but will rather speak of blessing, promotion, a job, house, car and other good things' (Kgatle 2021:143). This NPP preaching that does not address sin in the church and is interested in material prosperity demonstrates the shift from a heavenly focused holiness movement to a this-worldly focused materialistic movement. This lack of a committed focus to heavenly confrontational preaching among NPPs has opened the room for the many controversial practices.

\section{The problem of prophetic celebrity cultism devoid of the holiness of God}

The section will attempt to demonstrate that South African NPPs use prophecy to construct celebrity cultism that is devoid of the fear of God's holiness which leads them to do the controversial activities reported among them.

\section{The use of prophecy to construct celebrity cultism}

Prophecy among NPPs is not just anthropocentric, it is also 'celebrity cultic' (Kgatle 2019:3, 2021:135-156; Resane 2017:3) because prophets use it to advance their cultic egos (Kgatle 2021) and to control their followers. Other cultic tendencies observed by Kgatle (2021) among NPPs are religious, secret, sex and money. Some NPPs use prophecy to construct their celebrity cult which they use to perpetrate the other cultic tendencies identified by Kgatle (2021). Neo-Pentecostal prophets have a celebrity view of prophecy that centres around special anointed 'men and women of God'. Classical conservative Pentecostalism has a communal view of prophecy, the 'prophethood' of believers' (Lum 2018:53), derived from Acts 2:16-18 as the fulfilment of the promise in Joel 2:28-29 that the outpouring of the Holy Spirit will result in all believers prophesying, regardless of their age and gender. However, NPPs are celebrated as the only unique ones who are specially chosen by God to do prophetic work. This tendency of limiting the gift of prophecy to special people, creates personality cultism in the NPPs.

Kgatle (2019:3) defines a celebrity cult as 'a cult of personality that arises when an individual becomes more important than the mission he or she belongs to'. Celebrity cult is different from respecting, or honouring church leaders and recognising their God-given authority over the church as taught in the Bible (Tm 15:12-13, Heb 13:7, 17). On the other hand, celebrity cult is the 'cult of personality' or the veneration of an individual that primarily involves the elevation of the persona of the individual above the mission or organisation they belong to. Pisch (2016:53) uses E.A. Rees' definition of leader cult to define personality cult. According to Rees (2004):
A leader cult is an established system of veneration of a political leader, to which all members of society are expected to subscribe, a system that is omnipresent and ubiquitous and one that is expected to persist indefinitely. It is thus a deliberately constructed and managed mechanism, which aims at the integration of the political system around the leader's persona. (p. 4)

Rees' definition of cult leader draws from Nikita Khrushchev' use of the term 'cult of the individual' to criticise Stalin's despotism in the Soviet Union. This is the veneration or idolisation of the leader making their persona the centre of the organisation's essence and making them more prominent than the organisation to the extent that followers are more committed to the leader than the organisation. From examining various definitions of personality cult Pisch (2016) explains that the key features of a personality cult:

$[A]$ re the elevation and glorification of an individual, the use of symbolism and ritual, the fact that the image or persona of the leader is manufactured and heavily managed, the use of mass media for the dissemination of the cult, and parallels to religious phenomena. (pp. 53-54) 
In other words, the personality cult or celebrity cultism amounts to the veneration of the leader and granting them pseudo-divine status. The NPPs promote their charismatic persona resulting in congregants coming to church to give their lives to the prophet instead of the Lord Jesus Christ, the founder of the church (Kgatle 2019:3). The controversial practices of the NPPs promote celebrity cultism that elevates the persona of the prophets over Christ and his church and its mission.

\section{The construction of celebrity cultism among neo-Pentecostal prophets}

The examples of the construction and entrenchment of the celebrity cultism in the NPPs abound. ${ }^{1}$ The common element is the culture of NPPs projecting themselves as being closer to God than other people which gives them a privileged status that puts them above other Christians. As mentioned earlier from Kgatle, NPPs construct their personality cult through forensic prophecy, prophetic titles, prophetic objects, prophetic consultation and prophetic miracles. As an example, the Malawian born prophet Shepherd Bushiri calls himself 'Major One'. ${ }^{2}$ Other supreme self-styled titles used by other prophets include 'Seer One', and 'Mzansi Prophet' (Kgatle 2021:6). Resane (2017:3) explains celebrity cultism as 'leadership "idols"' with ecclesiological and academic titles. The celebrity church leader has an image of a 'commander Pastor' 'whose attitudes, ego, and authority revolves around him [or her], not around God' (Resane 2017:5). In celebrity cultism, the church leader 'displays himself [or herself] as an achiever who desires the fame of the world' (Resane 2017:5). Thus, celebrity cultism involves promoting one's own name and brand instead of God's name. Therefore, when prophets make people eat grass and use their prophetic stature and authority to demand sex from women and money from congregants, the prophets display their power and not the power of God.

The prophetic titles assert the prophet's uniqueness and supremacy over church members and rival prophets. For example, Bushiri asserts his supremacy by producing video recordings showing him doing seemingly unrivalled deeds such as walking on the air (The Citizen 2015) and angels physically appearing in his church services (Scott Nkuba Official 2015). Bushiri further asserts his supremacy as a prophet through several personal testimonies that portray his unique relationship with God in comparison to others. One of Bushiri's (2019) testimonies that makes him stand out as uniquely closer to God and even higher than other prophets contains vivid descriptions of what he called his 'first encounter with heaven' at the age of 10, when he received his prophetic commission. Bushiri (2019) testifies that he saw God seated in his glorious throne with angels worshipping him in a song. He says Jesus came to him and

1.For a further discussion on how NPPs build up their personality cult see Kgatle (2021:3-5)

2.Interestingly, according to Kgatle (2019:1), Bushiri was introduced into the practice of prophecy by a Zimbabwean prophet Uebert Angel (native name Huber Mudzanire) who has since handed over his prophetic baton to Bushiri, and now calls himself 'a retired professor of prophecy'. they walked together while a great multitude of people climbed on trees to watch them. Bushiri adds that Jesus told him that the multitude symbolised the coming of a time when people would come from all over the world to search for God in him. Bushiri says God gave him the keys to access the ministries of the kingdom and God took him to paradise where nobody is allowed and he saw something like a monitoring screen that monitors everyone's life. He adds that God gave him the eyes to monitor people's lives and know their life situations. He narrates that God gave him power to move on earth and drag the devil with his hands and he was also given an invisible sword, and every time he stretched his hand the sword cuts every cord of the enemy. Bushiri narrates that God commissioned him to the earth to bruise Satan's feet. He adds that God warned him that he will face great opposition and persecution from many people. And God told him that no person would ever be able to understand him and he will kill anyone who manages to understand Bushiri, even if it is a close relative such as his wife or child. In the testimony, Bushiri effectively constructs his personality cult by saying God has destined him to be an unequalled prophet.

It is outside the scope of this article to question the veracity of Bushiri's claims of having experienced a heavenly encounter. However, Kgatle (2019:4) warns that 'Pentecostal prophecy [is] known for miracles whose authenticity is questionable'. Nonetheless, Bushiri's claims set him apart as a uniquely unparalleled 'man of God' who was initiated into prophecy by God, who walked with Christ and received admiration from angels and fear from other people. As an indication of his greatness, before the outbreak of COVID-19 his church attracted thousands of worshipers from across Africa, and many were practically willing to camp for hours to access him, even paying a lot of money, for an opportunity to meet or see him (Kgatle 2019:2).

The concern about celebrity prophetism is that salvation is either taken away from Christ or placed on the prophet or the prophet acts as a mediator of God's salvation. The problem is that the prophets replace the authority of the gospel by their prophetic schemes. Furthermore, Bushiri's declaration that God would make him a mystery beyond understanding by all people and that God will kill anyone who manages to understand Bushiri, even if it is his wife or child, creates an idol by setting him above other people. These claims sacralise him as a person to be revered by all people. This also contains an element of instilling fear, by making people fear him as one possessing spiritual powers that harm anyone who scrutinises him, resists or opposes his wishes. Furthermore, given that at the time of writing Bushiri is facing charges of fraud and money-laundering in the South African courts (Jordaan 2019a; SowetanLive 2019), this kind of testimony acts as proof that God's word to him in his vision that people will fail to understand him, oppose and persecute him is being fulfilled. Furthermore, in this self-created personality cult all the accusations against him of producing fake miracles (Makhoba 2019) and criminal allegations are not just delegitimised as false accusations, but are conveniently 
appropriated as necessary to entrench his personality cult. Rather than being shameful of the disgraceful events that should expose Bushiri as a religious fraud, all these accusations and court trials, no matter how serious their nature, are therefore deemed necessary badges of honour to authenticate the fulfilment of God's promises to him when he chose and commissioned him to the prophetic ministry.

Bushiri's claims that God sent him to crush Satan and that God gave him an invisible sword persuades his followers to rather focus on his ultimate victory over his accusers, instead of being concerned about the seriousness of the allegations made against him. While it is almost impossible to refute Bushiri's personal testimony, a serious problem it presents is that it tramples on God's holiness. His self-sacralisation makes the young girls who allege to have been raped by him (McCain 2021), the people who claim to have been defrauded of their life's saving by him (Mashego 2019), and all who accuse him of wrongdoing, to be seen as enemies of God that will surely be crushed and be cut by the invisible sword given to him by God. Bushiri's statement effectively scares off anyone who dares to question and scrutinise him. An even bigger problem with Bushiri's self-projection as a powerful prophet is that the demonstration of spiritual power seems much more important than the prophetic proclamation of the gospel of Jesus Christ (Kgatle 2019:5). In this scheme of things, the truth of the gospel loses its authoritative pre-eminence to the drama of miracles.

However, a serious issue in prophetic celebrity cultism is the role played by the followers in promoting, upholding and defending celebrity cultism of the prophets (Rukwati 2012), as it is also built by the followers' refusal to have the prophets held accountable for their actions. For instances when the Commission for the Promotion and Protection of the Rights of Cultural, Religious and Linguistic Communities (CRL Rights Commission) ${ }^{3}$ summoned prophets to the hearings on investigations of commercialisation of religion, the followers of the prophets stormed the venues and disrupted proceedings, threatening and insulting officials as a way of preventing their Prophets from being questioned by the investigating panel (CRL Rights Commission 2017:17-19). Similarly, the court trials of Pastor Timothy Omotoso in Port Elizabeth (Manona 2017) and Bushiri in Pretoria witnessed throngs of supporters who mocked the court proceedings as a fight against God (Radebe 2020). Thus, while many ordinary followers often do not have the critical skills to scrutinise their faith, celebrity cultism is also actually constructed by followers who sacralise their prophets and pledge unquestioning allegiance to them. It is common to hear followers of NPPs declare themselves as children of the prophets. The Bible indeed does have a concept of spiritual parents and spiritual children (1 Cor 4:15, Tm 1 1:2), however, in the NPP churches this concept is often applied in an uncritical and destructive manner that gives the

3.The CRL Rights Commission is the Commission for the Promotion and Protection of the Rights of Cultural, Religious and Linguistic Communities, an independent state the Rights of Cultural, Religious and Linguistic Communities, an independent state
body overseeing religious, cultural and linguistic issues, to recommend the strict regulation of religion in South Africa. prophets the role and authority in the believer's life that ought to be given to God (Dube 2018). ${ }^{4}$

\section{The lack of God's holiness in the celebrity prophecy of neo-Pentecostal prophets}

As can be seen above, a critical problem with celebrity cultism is the lack of the fear of God which ultimately becomes a licence for the prophets to do the reported unholy activities. Here a foundational problem is that the NPPs have a distorted doctrine of God that does not instil a reverent fear of God. Instead, their distorted doctrine of God allows them to do the ungodly activities reported among them.

NPP prophecy that lacks the fear of God functions as an instrument of commercialising religion and abusing people's trust in the prophets instead of functioning as means of proclaiming and reinforcing God's holiness. The fact that the CRL Rights Commission (2017) concluded its report on its investigations on the commercialisation of religion and abuse of people's beliefs systems in South Africa by calling on the government to regulate religion, speaks volumes about the lack of the fear of God in the country's churches. Ultimately, the report found that the commercialisation and abuse of religion was because of the lack of fear of God and the state needed to fill that vacuum by instilling its fear on the religious practitioners. Concerning the NPPs, it can be said that they construct a prophetic celebrity cult that claims proximity to God but does not demonstrate any fear or reverence for him.

It can also be said that NPPs have built their popularity by dramatic but questionable practices such as making people eat grass and use of things such as dog meat, which are offensive even to non-religious people and therefore bring a mockery to God's holy name. The reported prophets show a lack of the fear of God's name by using it to sexually violate women and young girls and also demand money to bless and pray for people in need. As Kgatle (2021:137) points out, 'the big problem with celebrity prophets, however, is the source of their wealth, which often is money from the poor'. This lack of fear of God leads to religiosity that lacks respect for the human rights and the congregants by subjecting them to harmful and dehumanising activities.

However, the lack of the fear of God can also be noted among followers who easily grant the prophets power that belongs to God over their lives. It is true that NPPs use their prophetic position to instil fear on their followers to force or manipulate them to yield to their selfish needs. However, it can also be argued that the spiritual fear instilled by the NPPs on their followers thrives on the followers' own lack of understanding of God's holiness. A sound understanding of God's holiness should empower the followers to not be gullible and to resist

4.Dube (2020) critiques the concept of spiritual parenting African Pentecostalism and says that while it provides alternative kinship ties and economic ties for people who experience economic and social chall
concept is exploitative and oppressive. 
and criticise the unholy use of prophecy by their prophetic leaders. A critical understanding of God's holiness should enable Christians in NPP churches to refuse the prophets' from usurping God's place and authority in their lives and even end up replacing God in the lives of the believers.

\section{The challenge of God's holiness to controversial neo-Pentecostal practices}

The holiness of God is proposed as bulwark against the controversial South African neo-Pentecostal practices that are abusive and dehumanising to the congregants and also harm the testimony of the church and the Christian religion.

\section{Holiness as God's ontological excellence}

The holiness of God challenges the NPPs to act in reverent fear of God and desist from activities that bring God's name and his church into disrepute. Instead of satisfying their personality cult, NPPs should ensure that their activities adhere to God's holiness. Various biblical texts affirm holiness as a communicable attribute of God that he shares with humanity, for example, 'consecrate yourselves therefore, and be holy, for I am holy' (Lv 11:44). A communicable attribute is character that is found in God and in humanity. As an attribute of God, holiness shows God's ontological state of purity and determines how he relates with his people and also regulates how people should relate with him as their God and how they should conduct themselves towards God and other people. The Bible presents God declaring his holiness: 'I, the Lord your God I am holy' (Lv 19:2). The holiness of God is an important theme in the Bible that describes his unparalleled uniqueness from other gods and human beings. For example, Hannah declares in her song, "There is no-one holy like the Lord; there is no-one besides you; there is no rock like our God' (1 Sm 2:2). Webster (2004:256) reflects on this verse from Hannah's prayer and concludes, 'God's holiness is his "majestic incomparability"' (italics original). Hannah asserts God's majestic incomparability by declaring that there is none holy like God. Commenting on this declared exclusive holiness, Webster (2004:256) adds, 'First and foremost, talk of God as holy simply betokens his utter uniqueness, his being as himself and not another'. In other words, holiness is an eternal intrinsic quality of God's ontology, without which he cannot be the God of the Bible, for holiness originates from him and it is him who determines the content of holiness (Webster 2004:256). This means that first and foremost, as an ontological characteristic of God, we must not think of God's holiness in comparative terms as if he began to be holy after humanity sinned and or when evil became operational. Rather, holiness is God's eternal nature.

Unpacking the meaning of holiness, Horton (2011:268) explains that the Hebrew word for 'holy' ( $q \bar{o} \underline{d} e s ̌)$ derives from the verb 'to cut out or separate', and in Greek is translated as hagios from the verb hagiazö to make holy. Employed in general terms, holy 'underscores the Creator-creature distinction' (Horton 2011:268). In essence, 'God's holiness is therefore his sheer "difference"' (Webster 2004:256). God is holy in his distinction as one who is distinct from his creatures by his own glorious majestic nature as one who dwells in unapproachable light (Tm 1 6:16). Furthermore, holiness depicts God's ontological nature for 'in his communicable and incommunicable attributes, God is qualitatively distinct from us' (Horton 2011:268).

Webster places the holiness of God within the triune ontology and shows that God's holiness is trinitarian and therefore relational. Webster (2004) puts it as:

The act in which God fulfils his holy being as Father, Son and Spirit differentiates him from every other being; as God enacts his majestic identity, he is entirely himself. Like all God's acts, this act of personal self-differentiation is wholly effortless, uncaused and perfect, requiring nothing for its fulfilment beyond itself. God's 'otherness' is not something that God comes to have in rivalry between himself and others. The divine being is replete, and is involved in no agonistics. God's holiness is thus his transcendence of any possible relation in which he is merely one factor alongside another, even if it be the supreme or victorious factor. There is none besides the holy God; he simply is. (p. 256)

The essence of Webster's statement is that holiness is what God is in his trinitarian being and in how he relates to his creatures. The emphasis that there is none besides the holy God affirms that God's holiness is an 'unrivalled difference' (Webster 2004:257). The prophet Isaiah presents a heavenly scene where seraphs continuously acknowledge God by proclaiming to each other, 'Holy, holy, holy is the Lord Almighty; the whole earth is full of his glory' (Is 6:3). A similar picture is presented in Revelation 4:8, where heavenly beings proclaim God's holiness non-stop, day and night. Thus, holiness depicts who is his being, and what he is in his nature.

\section{Holiness as God's active moral excellence}

In addition to a state of being, God's holiness is active and can be experienced in God's relationship with his people. While some biblical passages present people encountering God's holiness in the form of majestic state of being, other passages present holiness as encountered in the form of God's glorious action towards his people. For example, in the already noted passage from 1 Samuel 2, Hannah's confession that there is no-one holy like the Lord is prompted by God's answer of her prayer in ending her infertility by giving her a son. Similarly, Moses and the Israelites praise God for delivering them from Egypt and making a way for them in the Red Sea by proclaiming, among other things: 'Who among the gods is like you, Lord? Who is like you - majestic in holiness, awesome in glory, working wonders?' In both cases God demonstrates his holiness by miraculously saving his people from an undesirable or life-threatening situation. Hannah links God's uniqueness and human existence 'there is no rock 
like our God' (1 Sm 2:2b), thus God demonstrates his holiness by giving life to his people. It can therefore be said that God's holiness is foundationally in people's relationship with him and their confidence in him. By his holiness, God sustains his creatures.

A strong notion of God's holiness is 'ethical purity, which is especially evident against the backdrop of human sinfulness' (Horton 2011:268). The prophet Habakkuk (1:13) expressed God's holiness as ethical purity by stating: 'Your eyes are too pure to look on evil; you cannot tolerate wrongdoing'. Webster (2004:257) expounds on the words of Habakkuk by saying. 'Incomparable and different in his being and act as the three-in-one, God is pure. God's holiness is also moral holiness ... God's holiness is pure majesty' (italics original). As Grudem (1994:201) explains, 'God's holiness means that he is separated from sin and devoted to seeking his own honour'. This means that in relational terms God is separated from sin and evil and is devoted to his righteous honour and glory (Grudem 1994:201). In his devotion to his own moral righteousness, God is the most holy (Ps 71:22; 99:9), pure from all evil and dwells in the most holy place (Ps 24:3). According to James 1:13, 'God cannot be tempted by evil, nor does he tempt anyone' which means that God is morally pure it is impossible for him to do anything evil:

It [holiness] is unsullied by anything that is opposed to or outside his will; its difference includes its otherness from all that is polluted; it admits of no compromise or degradation of its perfection. But - crucially - moral perfection does not exhaust the notion of God's holiness, and is properly subordinate to holiness as God's incomparable identity. (Webster 2004:257)

Therefore, 'God's holiness especially marks the "ontological distinction" between Creator and creatures as well as the "ethical opposition" between God and sinners' (Horton 2011:268). In other words, holiness is God's active moral excellence and perfect moral purity.

\section{Holiness and God's people}

Various biblical texts argue that holiness, although essentially a divine attribute, human beings can possess it too. The holy God demands his people to be holy just as he is holy: 'You are to be holy to me because I, the Lord, am holy, and I have set you apart from the nations to be my own' (Lv 20:26). Holiness is a communicable attribute that God shares with his people by first, conferring it upon them and also demanding that they actively practice it in how they live before him and with one another (Lv 19:2, cf; 11:44-45; 20:26, Pt 1 1:16). Therefore, there are at least two aspects concerning the holiness of God's people, namely, a consecrated condition conferred by God on people and things (God makes his people holy) and an obligation God places on Christians that they must fulfil toward him (God's people must practically maintain a holy disposition by doing certain things or refraining from certain things).
Holiness as a state of condition conferred by God, means that he makes people and things holy by consecrating them for himself. Horton (2011:269) explains that after sin corrupted God's world which he originally created perfect and holy, and brought it under a curse, 'God elects Israel, calling Abram out of Ur, he makes holy that which is common, literally cutting $[q \bar{o} \underline{d} e s ̌]$ Israel out of the nations by circumcision' (Horton 2011:269). Israel is holy by being chosen by God, declared holy and exclusively dedicated to God. Likewise, certain days (Ex 20:11, cf. Gn 2:3), certain people, objects, human relationships (such a marriage) and activities (such as sex) are described as holy because of their direct association with God or because of certain unique value that he has placed upon them. In this perspective, holiness is a condition that God gives. Ephesians 1:4 describes Christians as chosen in Christ 'before the creation of the world to be holy and blameless in his sight'. This is a condition or state of being given by God to human beings.

Holiness includes obligations God places on Christians which they must fulfil toward him and other people. God commands Moses to charge Israel: 'Be holy because I, the LORD your God, am holy' (Lv 19:2). This means that: 'God's holiness provides the pattern for his people to imitate' (Grudem 1994:202). In the New Testament, Peter affirms the command by adding '[J]ust as he who called you is holy, so be holy in all you do; for it is written: "Be holy, because I am holy"' (Pt 115:16). In this verse, God commands his people to conform to his holiness by living and conducting themselves in ways that are pleasing to him as their God and bear testimony to their covenant relationship with him. Therefore, a foundational basis in God's demand for Israel to be holy is because holiness is a status conferred by God on his people (Lv 20:26).

As a moral attribute, holiness has vertical (towards God) and horizontal (towards other people) aspects. Vertically, God expects his people to treat him with respect and honour. In Old Testament, holiness contained decorum fitting with God's excellent nature in worship (e.g. Lv 22). The ungodly priests are punished not only because they committed sin, but because their actions violate God's holy decorum that ought to be observed towards him by his people (Lv 10:1-7, 1 Sm 2:12-17). The chaotic, abusive and immoral nature in some of the incidents reported among some NPPs violate the New Testament call for orderly worship that honours God's name.

Holiness is a serious issue to God that Christ had to die to sanctify the church to make it holy with his blood (Eph 5:26-27). The church just like Israel (Ex 19:4-6) is described as a 'holy nation' (Eph 2:21) to affirm the need for separation from evil and sin, and being devoted to God. Holiness is a serious issue to God: without holiness no one will see the Lord (Heb 12:14). Furthermore, holiness is demanded from Christians as individuals and collectively as the church (Eph 2:21). Ultimately, for Christians holiness is an eschatological reality that will be fully realised at Christ's return when $\sin$ is finally destroyed (Zch 14:20-21). 


\section{Towards a theological framework informed by God's holiness of responding to controversial neo- Pentecostal prophets}

From a systematic theological perspective, what changes should NPPs and their followers make in their belief systems in order to uphold the holiness of God in their churches?

\section{God's holiness means that the fear of God must govern all church practises}

At the bottom of the controversial activities of the NPPs is the lack of the fear of God. Fear of God refers to both the sense of being terrified and the reverence for God because of his holy nature. The allegations that prophets use God's name to rape and sexually exploit young vulnerable girls, demand money and possessions from desperate people and build their personality cult are signs that they neither respect God's holy name nor do they fear his justice that punishes evil. When one watches the videos and pictures of the various sacrilegious acts by NPPs such as making people eat grass, spray people with pesticides, make women wave their underwear in a worship service and use dog meat for communion, one is left asking: why are they not afraid that God's anger may burn against them and kill them like the priests Nadab and Abihu (Lv 10:1-2)? NPPs need to inform their view of ministry with the warning from Hebrews 12:28-29 that we should "worship God acceptably with reverence and awe, for our "God is a consuming fire"'. This means that NPPs should fear God as one who is holy and sovereign, and not treat him with disdain as if he is an expendable tool for one's selfish purposes. Furthermore, the fear of God should challenge them to desist from ecclesiological practices that desecrate the holiness of the church and dehumanise people. The first step towards a meaningful fear of God is a sound theology of God.

\section{God's holiness means that justice and righteousness must mark Christian ministry}

A direct consequence of fearing God is making justice and righteousness hallmarks of Christian ministry. Psalm 47:8 declares that holiness is the foundation of God's throne. In Psalm 89:14, righteousness and justice are said to be the foundation of God's throne - that is his kingdom. This means that righteousness and justice are expressions of God's holiness. Since the church is an instrument of the kingdom of God, it therefore means that the Christian ministry must be marked by justice and righteousness. In so far as the controversial works of the NPPs are concerned, there are two sides to this. On the one side: God's holiness demands that NPPs be agents of holiness by doing that which is right and just towards their congregants, the poor and sick who need their help. On the other hand, congregants must uphold the holiness of the church by rejecting the unjust and unrighteous practices of the NPPs. The question is: if the holy God is just and righteous, why should believers be willing to be subjected to unjust, humiliating and dehumanising religious practices?

\section{The holiness of God desacralises all spiritual authorities}

That it is God only who is holy disqualifies all human and spiritual authorities from absolutising themselves. Neo-Pentecostal prophets sacralise themselves through personality cultism and at the same time, gullible and uncritical congregants sacralise their prophets as great 'men and women of God' who should be treated as royalty. As taught in the Bible, Christians must indeed love, honour, respect and obey their leaders in the church, and they should indeed celebrate their leaders for the roles they play and the good work they do in God's church. However, this should be done knowing that these leaders are fully fallen human beings who are prone to many mistakes and misjudgements. This means that Christians should think carefully when they affix on their cars and houses stickers with their prophet's photo written: 'I am the child of the prophet'. Indeed, while church members must stand with their prophets and defend them when they are falsely accused and maligned, it is however objectionable when church members demonise victims of their prophets' evil actions, demonise, hinder and threaten state authorities and courts of law from bringing their prophets to account for the crimes and wrongdoing made against them. Followers of the NPPs often use the injunction, 'Do not touch my anointed ones; do my prophets no harm' (1 Chr 16:22) to sacralise their prophets and shield them from being held accountable for their questionable actions. Equally, that it is God only who is holy means that Christians should not allow any Christian leader to occupy in their lives a space and authority that ought to belong to the holy God.

\section{Holiness exclusively limits salvation to the work of God}

The holiness of God exclusively limits salvation to himself. In the controversial activities NPPs give the impression that people's salvation depends on them and that they can influence God in who he saves and heals. People are willing to be subjected to abusive, exploitative and dehumanising rituals by prophets as if the prophets have some power over their salvation and relationship with God. However, Christians need to realise that the only mediator between God and humanity is Christ, the only human being (in his human nature) who fulfilled God's holiness. As Paul stated it: 'For there is one God and one mediator between God and mankind, the man Christ Jesus' (Tm 1 2:5), which means that Christ is the only one who is holy enough to reconcile God and humanity. This means that Christians must not fear NPPs who act as if Christians' salvation and relationship with God depends on their prophetic work. God's holiness means that Christians must refuse to be subjected to unholy activities that are imposed on them by their prophets.

\section{Conclusion}

This article has attempted to wrestle with controversial NPPs from a systematic theological view that emphasises 
the role of Christian doctrines in regulating church worship and practice. The research question answered in the article was: how can an understanding of the holiness of God assist Christian believers to respond meaningfully to the controversial practices? The article argued that the controversial acts of the NPPs thrive on the undermining or lack of awareness of God's holiness which leads to the celebrity cult of the prophets. In the light of God's holiness, NPPs are urged to desist from their tendencies of celebrity cultism and anthropocentric prophetism that merely satisfies people's yearnings. Rather than celebrity cultism and human-centred prophetism, the holiness of God challenges the NPPs to fear God and embark on prophecy that upholds God's holy name, his love and salvation. Furthermore, instead of celebrity cultism, NPPs should be humble and Bible based (Kgatle 2019:6). Finally, the believing community must also not be gullible but instead take responsibility of their faith. Ordinary believers are repeatedly warned in the Bible to know the truth, be wary of false teachers and avoid being misled by miracle workers who subvert the truth of Scripture. For example, the apostle Paul warned: 'If anyone teaches otherwise and does not agree to the sound instruction of our Lord Jesus Christ and to godly teaching, they are conceited and understand nothing' (Tm 1 6:3-4a). This shows that every Christian must develop skills of identifying false teachers and escape from their dangerous traps. The contribution of the article lies in highlighting the importance of holiness of God as a standard of measuring the Christian authenticity of the activities of the NPPs in South Africa.

\section{Acknowledgements}

I would like to thank Dr Dambudzo Mbendana for reading the final draft of the manuscript and assisting with helpful comments for improvement, the Unit for Reformational Theology, and the Development of the South African Society, Faculty of Theology, for the support provided in the conducting of this research.

\section{Competing interests}

The author declares that he has no financial or personal relationships that may have inappropriately influenced him in writing this article.

\section{Author's contributions}

C.B. is the sole author of this research article.

\section{Ethical considerations}

This article followed all ethical standards for research without direct contact with human or animal subjects.

\section{Funding information}

This research received no specific grant from any funding agency in the public, commercial or not-for-profit sectors.

\section{Data availability}

Data sharing is not applicable to this article as no new data were created or analysed in this study.

\section{Disclaimer}

The views and opinions expressed in this article are those of the author and do not necessarily reflect the official policy or position of any affiliated agency of the author.

\section{References}

Anderson, A.H., 2013, To the ends of the earth: Pentecostalism and the transformation of world Christianity, Oxford University Press, New York, NY.

Bushiri, S., 2019, My encounter in heaven, viewed 18 May 2021, from https://www. youtube.com/watch?v=Hwtp3bpSv3A.

Chimuka, T.A., 2013, 'Reflections on the morality of some prophetic acts in Zimbabwe's Pentecostal movements', in E. Chitando, M.R. Gunda \& J. Kügler (eds.), Prophets, profits and the Bible in Zimbabwe: Festschrift for Aynos Masotcha Moyo, pp. 113-132, University of Bamberg Press, Bamberg.

Chimuka, T.A., 2016, 'Afro-Pentecostalism and contested holiness in southern Africa', Studia Historiae Ecclesiasticae 42(1), 124-141. https://doi.org/10.25159/2412 4265/307

CRL Rights Commission, 2017, Report on the hearings on the commercialisation of religion and abuse of people's beliefs systems, viewed 29 June 2021, from https:// www.gov.za/sites/default/files/gcis_document/201708/report-commecialization ofreligionandabuseofpeoplesbelievesystems.pdf.

Dube, B., 2020, “'Go and prophesy in your own land": Foreign prophets and popularism in South Africa, Evoking the need of Jonathanic theology for peaceful resolution of difference', Religions 11(1), 42. https://doi.org/10.3390/rel11010042

Dube, Z., 2018, 'Patriarchy reinvented? "Spiritual parenting" within African Pentecostalism in Zimbabwe', Verbum et Ecclesia 39(1), a1777. https://doi. org/10.4102/ve.v39i1.1777

eNCA, 2019, Mboro takes on Lukau, viewed 19 April 2020, from https://www.youtube. $\mathrm{com} /$ watch? $v=$ wqJtYBMkvpc\& $\mathrm{t}=11 \mathrm{~s}$.

Grenz, S.J. \& Olson, R.E, 1996, Who needs theology?: An invitation to the study of God, InterVarsity Press, Downers Grove, IL.

Grudem, W.A., 1994, Systematic theology: An introduction to biblical doctrine, InterVarsity Press, Leicester.

Horton, M., 2011, The Christian faith: A systematic theology for pilgrims on the way, Zondervan, Grand Rapids, MI.

Jordaan, N., 2019a, 'Prophet' Bushiri to stand trial next year on fraud and money laundering charges, viewed 17 February 2020, from https://www.timeslive.co.za/ news/south-africa/2019-11-29-prophet-bushiri-to-stand-trial-next-year-onfraud-and-money-laundering-charges/.

Jordaan, N., 2019b. 'Stop lying in God's name' - Mboro demands to see pastor Alph Lukau, viewed 19 April 2020, from https://www.timeslive.co.za/news/southafrica/2019-02-28-lets-not-fake-things-pastor-mboro-implores-pastor-alphlukau/.

Kgatle, M.S., 2019, 'Reimagining the practice of Pentecostal prophecy in Southern Africa: A critical engagement', HTS Teologiese Studies/Theological Studies 75(4), a5183. https://doi.org/10.4102/hts.v75i4.5183

Kgatle, M.S., 2020, 'New paradigms of pneumatological ecclesiology brought about by new prophetic churches within South African Pentecostalism', Verbum et Ecclesia 41(1), a2053. https://doi.org/10.4102/ve.v41i1.2053

Kgatle, M.S., 2021, Pentecostalism and cultism in South Africa, Palgrave-Macmillan, Cham.

Lum, L.M.D., 2018, The practice of prophecy: An empirical-theological study of Pentecostals in Singapore, Pickwick Publications, Eugene, OR.

Makhoba, N., 2019, Shepherd Bushiri: Malawians say they saw through the prophet of profit, viewed 26 June 2021, from https://www.news24.com/citypress/news/ shepherd-bushiri-malawians-say-they-saw-through-the-prophet-ofprofit-20190211.

Manona, N., 2017, Worshippers fill up PE court in support of pastor accused of sexual assault, viewed 26 June 2021, from https://www.news24.com/citypress/news/ worshippers-fill-up-pe-court-in-support-of-pastor-accused-of-sexualassault-20170421.

Mashego, A., 2019, 'Robbed' from the pulpit: How Bushiri conned investors out of millions, viewed 26 June 2021, from https://www.news24.com/citypress/news/ robbed-from-the-pulpit-how-bushiri-conned-investors-out-of-millions-20190225.

McCain, N., 2021, Self-proclaimed prophet Shepherd Bushiri faces rape chargesreport, viewed 22 April 2021, from https://www.news24.com/news24/ SouthAfrica/News/self-proclaimed-prophet-shepherd-bushiri-faces-rapecharges-report-20210319.

Multimedia Live, 2019, 'His time has come to an end' - Prophet Mboro lays charges against pastor Lukau, viewed 19 April 2020, from https://www.youtube.com/ watch?v=86Ks43zaBbE. 
Pisch, A., 2016., The personality cult of Stalin in Soviet posters, 1929-1953: Archetypes, inventions and fabrications, ANU Press, Acton.

Radebe, R., 2020, In pictures: Bushiri supporters in high spirits as court grants bail, viewed 26 June 2021, from https://www.timeslive 11-04-in-pictures-bushiri-supporters-in-high-spirits-as-court-grants-bail/.

Ramantswana, H., 2019, 'Prophets praying for, or preying on people's faith: A reflection on Prophetic Ministry in the South African context', In Die Skriflig 53(4), a2495. https://doi.org/10.4102/ids.v53i4.2495

Rees, E.A., 2004, 'Leader cults: Varieties, preconditions and functions', in B. Apor, J. Behrends, P. Jones \& E. Rees (eds.), The leader Cult in Communist Dictatorships: Stalin and the Eastern Bloc, pp. 3-26, Palgrave Macmillan, Basingstoke.

Resane, K.T., 2017, “'And they shall make you eat grass like oxen" (Daniel 4:24): Reflections on recent practices in some New Charismatic churches', Pharos Journal of Theology 98(1), 1-17.
Rukwati, T., 2012, Prophets mustn't be questioned, viewed 17 March 2017, from $\mathrm{http}: / / \mathrm{www}$.herald.co.zw/prophets-mustnt-be-questioned/.

Scott Nkuba Official, 2015, Angels in church appears physically: Prophet Shepherd Bushiri, viewed 18 May 2021, from https://www.youtube.com/watch?v=9WelgQxowjs.

SowetanLive, 2019, Controversial church leader Shepherd Bushiri arrested, viewed 24 January 2020, from https://www.sowetanlive.co.za/news/south-africa/2019-02 01-controversial-church-leader-shepherd-bushiri-arrested/.

The Citizen, 2015, Video: Prophet Bushiri 'walks on air', viewed 18 May 2021, from https://citizen.co.za/news/news-eish/786990/video-prophet-bushiri-walkson-air/.

Tsekpoe, C., 2019, 'Contemporary prophetic and deliverance ministry challenges in Africa, Transformation 36(4), 280-291. https://doi.org/10.1177/0265378819866217

Webster, J., 2004, 'The holiness and love of God', Scottish Journal of Theology 57(3), 249-268. https://doi.org/10.1017/S0036930604000250 